\title{
Устойчивость местных форм овса из Кавказского региона к обыкновенной злаковой тле
}

Радченко Е.Е.*, д.б.н., г.н.с.; Чумаков М.А., к.б.н., м.н.с.; Лоскутов И.Г., д.б.н., г.н.с.

Федеральный исследовательский иентр Всероссийский институт генетических ресурсов растений имени Н.И. Вавилова, С.-Петербург, Россия.

*e-mail: eugene_radchenko@rambler.ru

Изучили устойчивость 124 местных образиов овса из стран Кавказа (Армения, Азербайджан, Грузия), а также из Северного Кавказа РФ (Дагестан, Ингушетия, Северная Осетия, Кабардино-Балкария) к краснодарской популяции обыкновенной злаковой тли. Выделили 5 устойчивых форм; 25 образиов гетерогенны по изученному признаку. Наиболее высокий уровень устойчивости выявлен у образиов к-7081 (Кабардино-Балкария) и к-9113 (Северная Осетия). Эти образиы защищеены аллелями генов устойчивости, отличаюшимися от идентифицированных ранее Grb1 и Grb3.

Ключевые слова: овес, Schizaphis graminum, устойчивость, селекиия растений.

\section{Greenbug resistance in oat landraces from Caucasus}

Radchenko E.E., Chumakov M.A., Loskutov I.G.

Federal Research Center the N.I. Vavilov All-Russian Institute of Plant Genetic Resources, St. Petersburg, Russia

e-mail: eugene_radchenko@rambler.ru

One hundred and twenty-four landraces from the Caucasian countries (Armenia, Azerbaijan, Georgia), as well as from the Northern Caucasus region of the Russian Federation (Dagestan, Ingushetia, North Ossetia, Kabardino-Balkaria), were assessed for greenbug resistance. The Krasnodar insect population was used in the experiments. We identified 5 resistant forms; 25 accessions are heterogeneous according to the studied trait. The highest level of resistance was found in accessions k-7081 (Kabardino-Balkaria) and k-9113 (North Ossetia). These accessions are protected by alleles of resistance genes which differ from the earlier identified Grb1 and Grb3.

Key words: oat, Schizaphis graminum, resistance, plant breeding.

Обыкновенная злаковая тля Schizaphis graminum Rondani - опасный вредитель овса и других зерновых культур на юге России. Селекция устойчивых сортов - радикальный и экологически безопасный способ борьбы с насекомым. Дифференциальное взаимодействие $S$. graminum с растениями-хозяевами обусловливает необходимость поиска новых доноров устойчивости. 
Литературные сведения об устойчивости овса к $S$. graminum скудны. Устойчивость образца Russian 77 к биотипу А тли контролируется доминантным геном [4]. Линии PI 186270 (Аргентина) и CI 1580 (Шотландия) имеют по одному доминантному гену устойчивости (Grb1 и Grb2 соответственно) к биотипу C; линия CI 4888 (Италия) защищена доминантным геном устойчивости Grb3 к биотипу тли В [3]. Ген Grb2 эффективен также к биотипам Е [9], I [5] и, лишь отчасти, к F - Н [6, 7].

Изучили устойчивость к $S$. graminum 371 образца овса из стран Азии и Дальнего Востока РФ и выделили 95 гетерогенных форм. Отобрали 7 устойчивых линий и показали, что эти формы защищены разными аллелями генов устойчивости, которые отличаются от гена Grb3 [8]. В результате оценки 191 образца овса из Армении, Азербайджана, Грузии и Дагестана выделили образец к-4308 с высокой устойчивостью к тле и 38 гетерогенных форм [2].

Результаты исследований свидетельствуют о высокой частоте устойчивых к вредителю форм среди коллекционного материала овса из Кавказа. Цель настоящей работы - завершить изучение наследственного разнообразия овса из кавказского региона по устойчивости к насекомому.

В лабораторных опытах оценили устойчивость к S. graminum 124 местных образцов овса из стран Кавказа (Армения, Азербайджан, Грузия), а также из Северного Кавказа РФ. Кроме того, тестировали образцы с генами устойчивости Grb1 (к-13903, PI 186270, Аргентина) и Grb3 (к-13902, CI 4888, Италия). Использовали краснодарскую (Кубанская опытная станция ВИР) популяцию тли и выделенные из нее клоны.

$S$. graminum некротизирует растительную ткань в месте питания, что позволяет тестировать поврежденность растений. Опытные образцы и неустойчивый контроль (сорт Borrus) высевали рядами в кюветы с почвой. В фазу двух листьев на растения стряхивали насекомых. При гибели контроля определяли поврежденность растений по шкале от 0 (нет повреждений) до 10. Растения с баллами 1-4 относили к устойчивым, 9-10-к восприимчивым [1].

Клоны с различными фенотипами вирулентности (“тест-клоны”) использовали для идентификации генов устойчивости у выделенных форм овса. Если хотя бы один клон, авирулентный к тестеру данного гена устойчивости, повреждает изучаемый сорт, это означает, что сорт не имеет функционального аллеля данного гена. Опытные образцы, тестеры двух $G r b$-генов и восприимчивый контроль высевали в сосуды с почвой в круговом порядке и закрывали изоляторами. В фазе 2-х листьев всходы заселяли тлями одного клона и при гибели контроля оценивали поврежденность растений по шкале.

Выявили 5 устойчивых форм; 25 образцов гетерогенны по изученному признаку. Наиболее высокий уровень устойчивости (1-4 балла) выявлен у образцов к-7081 (Кабардино-Балкария) и к-9113 из Северной Осетии 
(табл. 1). Поврежденность растений образцов к-4818, к-4839 (Армения) и к10107 (Азербайджан) варьировала в более широких пределах (2-6 баллов), а ряда других образцов - от 2 до 10 баллов. Значительная изменчивость признака может обусловливаться проявлением генов с низкой экспрессивностью и/или присутствием в популяции фитофага клонов с различной вирулентностью к изученным формам.

Таблица 1 - Образцы местного овса, выделившиеся по устойчивости к S. graminum

\begin{tabular}{|c|c|c|c|c|c|c|}
\hline \multirow{2}{*}{$\begin{array}{c}\text { Номер } \\
\text { по } \\
\text { ката- } \\
\text { логу } \\
\text { ВИР }\end{array}$} & \multirow[t]{2}{*}{ Разновидность } & \multirow[t]{2}{*}{ Происхождение } & \multirow[t]{2}{*}{$\begin{array}{l}\text { Оценено } \\
\text { растений }\end{array}$} & \multicolumn{3}{|c|}{$\begin{array}{c}\text { Распределение расте- } \\
\text { ний по баллам повре- } \\
\text { жденности, \% }\end{array}$} \\
\hline & & & & $1-4$ & $5-8$ & 9,10 \\
\hline 4046 & aristata & Грузия & 41 & 9,8 & 63,4 & 26,8 \\
\hline 4178 & aristata & Армения & 36 & 25,0 & 2,8 & 72,2 \\
\hline 4511 & mutica, aristata & Грузия & 39 & 23,1 & 23,1 & 53,8 \\
\hline 4818 & aristata & Армения & 20 & 70,0 & 30,0 & - \\
\hline 4839 & aristata & Армения & 21 & 52,3 & 47,6 & - \\
\hline 4858 & aristata, $\mathrm{mor}$ & Азербайджан & 34 & 11,8 & 11,8 & 76,4 \\
\hline 6531 & aristata & Ингушетия & 47 & 29,8 & 29,8 & 40,4 \\
\hline 7040 & aristata & Дагестан & 40 & 42,5 & 37,5 & 20,0 \\
\hline 7041 & aristata & Дагестан & 38 & 10,5 & 26,3 & 63,2 \\
\hline 7049 & brunnea, setosa & Северная Осетия & 37 & 35,1 & 56,8 & 8,1 \\
\hline 7062 & aristata, mutica & Северная Осетия & 39 & 23,1 & 17,9 & 59,0 \\
\hline 7065 & aristata, mutica & Северная Осетия & 38 & 36,8 & 44,8 & 18,4 \\
\hline 7072 & aristata & Кабардино-Балкария & 35 & 11,4 & 8,6 & 80,0 \\
\hline 7075 & aristata, mutica & Кабардино-Балкария & 39 & 28,2 & 23,1 & 48,7 \\
\hline 7077 & aristata, mutica & Кабардино-Балкария & 33 & 45,5 & 51,5 & 3,0 \\
\hline 7079 & aristata, mutica & Кабардино-Балкария & 36 & 30,6 & 36,1 & 33,3 \\
\hline 7080 & aristata, mutica & Кабардино-Балкария & 45 & 37,8 & 57,8 & 4,4 \\
\hline 7081 & aristata, mutica & Кабардино-Балкария & 20 & 100 & - & - \\
\hline 8329 & mutica & Дагестан & 28 & 21,4 & 7,2 & 71,4 \\
\hline 9109 & $\begin{array}{l}\text { aristata, mutica, } \\
\text { aurea }\end{array}$ & Кабардино-Балкария & 34 & 20,6 & 23,5 & 55,9 \\
\hline 9113 & mutica, aristata & Северная Осетия & 23 & 100 & - & - \\
\hline 9114 & mutica, aristata & Северная Осетия & 30 & 50,0 & 33,3 & 16,7 \\
\hline 9116 & mutica, aristata & Кабардино-Балкария & 30 & 43,3 & 50,0 & 6,7 \\
\hline 9117 & aristata, mutica & Кабардино-Балкария & 31 & 12,9 & 54,8 & 32,3 \\
\hline 10107 & mutica & Азербайджан & 22 & 40,9 & 59,1 & - \\
\hline 10398 & mutica & Грузия & 34 & 32,3 & 32,3 & 35,4 \\
\hline 10399 & aristata, mutica & Дагестан & 36 & 11,1 & 2,8 & 86,1 \\
\hline 10429 & aristata, brunnea & Дагестан & 30 & 3,3 & - & 96,7 \\
\hline 10907 & cinerea & Азербайджан & 34 & 29,4 & 23,5 & 47,1 \\
\hline 12373 & mutica & Грузия & 37 & 24,3 & 73,0 & 2,7 \\
\hline 11840 & Borrus (контроль) & Германия & 165 & - & - & 100 \\
\hline
\end{tabular}


Наибольшее число генотипов (9, или 40,9 \% от числа изученных), у которых поврежденность устойчивых компонентов не превышала четырех баллов, выделено среди образцов из Кабардино-Балкарии. Встречаемость устойчивых форм высока среди образцов овса из Азербайджана: 3 из семи изученных образцов $(42,9 \%)$ несут отчетливо проявляющиеся гены устойчивости, затем следуют образцы из Армении (37,5 \%), Грузии (23,5 \%), Ингушетии (25\%), Дагестана (16,1\%) и Северной Осетии (14,3\%).

Оценили устойчивость образцов к-7081 и к-9113, а также линий с генами Grb1 и Grb3, к десяти клонам тли. При заселении растений наиболее «информативными» клонами, вирулентными к линиям овса из Италии и Аргентины, наблюдали устойчивость образцов из Северного Кавказа (табл. 2), то есть эти формы защищены аллелями генов устойчивости, нетождественными $G r b 1$ и $G r b 3$. На различие генетического контроля устойчивости к $S$. graminum у выделенных форм и линии к-13902 указывает и взаимодействие образцов с клонами, имеющими фенотип вирулентности 2.

Таблица 2 - Устойчивость образцов овса к клонам S. graminum

\begin{tabular}{|l|l|c|c|c|}
\hline \multirow{2}{*}{ Образец } & \multirow{2}{*}{ Происхождение } & \multicolumn{3}{|c|}{ Тест-клоны S. graminum } \\
\cline { 3 - 5 } & & 1 & 2 & 3 \\
\hline к-7081 & Кабардино-Балкария & $\mathrm{R}^{*}$ & $\mathrm{R}$ & $\mathrm{R}$ \\
\hline к-9113 & Северная Осетия & $\mathrm{R}$ & $\mathrm{R}$ & $\mathrm{R}$ \\
\hline к-13902 (СI 4888) & Италия & $\mathrm{R}$ & $\mathrm{S}$ & $\mathrm{S}$ \\
\hline к-13903 (РІ 186270) & Аргентина & $\mathrm{R}$ & $\mathrm{R}$ & $\mathrm{S}$ \\
\hline
\end{tabular}

* $\mathrm{R}$ - устойчивость образца; $\mathrm{S}$ - восприимчивость.

Результаты наших экспериментов продемонстрировали высокую (до $43 \%$ частоту устойчивых к обыкновенной злаковой тле образцов среди местных форм овса из кавказского региона. Выделили 5 резистентных форм, среди которых наиболее высоким уровнем устойчивости характеризуются к7081 (Кабардино-Балкария) и к-9113 (Северная Осетия). Эти образцы защищены аллелями генов, отличающимися от идентифицированных ранее Grb1 и Grb3. Выделили также 26 гетерогенных образцов, которые после отбора по устойчивости могут быть использованы в селекции на иммунитет.

Благодарности: Исследование выполнено при поддержке РФФИ (грант № 20-016-00048) и бюджетного проекта № 0662-2019-0006.

\section{Список литературы}

1. Радченко Е. Е. Злаковые тли // В кн.: Изучение генетических ресурсов зерновых культур по устойчивости к вредным организмам. Методическое пособие. М.: Россельхозакадемия, 2008. - С. 214-257.

2. Радченко Е.Е., Чумаков М.А., Лоскутов И.Г. Устойчивость образцов овса из Дагестана и стран Кавказа к обыкновенной злаковой тле // Труды по прикладной ботанике, генетике и селекции. - 2019. - Т. 180. - № 3. - С. 106-109. DOI: 10.30901/2227- 
8834-2019-3-106-109

3. Boozaya-Angoon D., Starks K.J., Edwards L.H., Pass H. Inheritance of resistance in oats to two biotypes of the greenbug // Environm. Entomol. - 1981. - V . 10. - № 4. - P. 557-559. DOI: 10.1093/ee/10.4.557

4. Gardenhire J.H. Inheritance of greenbug resistance in oats // Crop Sci. - 1964. V. 4. - № 4. - P. 443. DOI:10.2135/cropsci1964.0011183X000400040041x

5. Harvey T.L., Kofoid K.D., Martin T.J., Sloderbeck P.E. A new greenbug virulent to E-biotype resistant sorghum // Crop Sci. - 1991. - V. 31. - № 6. - P. 1689-1691. DOI: 10.2135/cropsci1991.0011183X003100060062x

6. Kindler S.D., Spomer S.M. Biotypic status of six greenbug (Homoptera: Aphididae) isolates // Environ. Entomol. - 1986. - V. 15. - № 3. - P. 567-572. DOI: 10.1093/ee/15.3.567

7. Puterka G.J., Peters D.C., Kerns D.L., Slosser J.E., Bush L., Worrall D.W., McNew R.W. Designation of two new greenbug (Homoptera: Aphididae) biotypes G and H // J. Econ. Entomol. - 1988. - V. 81. - № 6. - P. 1754-1759. DOI: 10.1093/jee/81.6.1754

8. Radchenko E.E., Kuznetsova T.L., Chumakov M.A., Loskutov I.G. Greenbug (Schizaphis graminum) resistance in oat (Avena spp.) landraces from Asia // Genetic Res. Crop Evol. - 2018. - V. 65. - № 2. - P. 571-576. DOI: 10.1007/s10722-017-0554-9

9. Starks K.J., Burton R.L., Merkle O.G. Greenbugs (Homoptera: Aphididae) plant resistance in small grains and sorghum to biotype E // J. Econ. Entomol. - 1983. - V. 76. № 4. - P. 877-880. DOI: 10.1093/jee/76.4.877

\section{Разнообразие генофонда дикорастущих видов секции Petota Dumort. рода Solanum L. для современной селекции картофеля}

Рогозина Е.В. *1, Чалая Н.A. ${ }^{1}$, Кузнеияова M.A. ${ }^{2}$, Бекетова М.П. ${ }^{3}$, Хавкин Э.Е. ${ }^{3}$

${ }^{1}$ Федеральный исследовательский центр Всероссийский институт генетических ресурсов растений им. Н.И. Вавилова (ВИР), Санкт-Петербург, Россия,

${ }^{2}$ Всероссийский научно-исследовательский институт фитопатологии, Московская область, Б. Вяземы, Россия,

3 Всероссийский научно-исследовательский институт сельскохозяйственной биотехнологии, Москва, Россия.

*e-mail: erogozina@vir.nw.ru

В коллекции ВИР выделены образцы диких клубнеобразующих видов Sоlaпuт L. и межвидовых гибридов - источники устойчивости картофеля к фиmофторозу (Phytophthora infestans (Mont.) de Bary), Y вирусу картофеля (YВK), золотистой картофельной нематоде nатотипа Rol (Globodera rostochiensis (Wollenweber) Behrens). Методом ПЦР с помощью ДНКммаркеров генов R1, R3a, R3b, RB/Rpi-blb1, Rpi-vnt1, Rysto, Ryadg, Rychc, H1, Gro1-4 проведен скрининг этой коллекции генотипов картофеля. Структурные гомологи генов устойчи- 